\title{
Policy Proposals to the Directorate General of Taxes related to System Improvement and Internet Network Access Difficulties
}

\author{
Abdi Ibrahim (BC201120032) - Fs. Bahari (BC201120017) - Muh. Takdir (BC201120014) \\ Dewi Shintawati Kusnadi (BC201120015) - Heisye Manderos (BC201120029) - Nixon (BC201120039) \\ Zulfia (BC201120026) - Agus Romdani (BC201120044) - Triadi Wijaya Syahrir (BC201120050) \\ Handryno (BC201120020) \\ ${ }^{1}$ Graduate in Institut STIAMI, Jakarta $-{ }^{2}$ Graduate in Institut STIAMI, Jakarta
${ }^{3}$ Graduate in Institut STIAMI, Jakarta $-{ }^{4}$ Graduate in Institut STIAMI, Jakarta
${ }^{5}$ Graduate in Institut STIAMI, Jakarta $-{ }^{6}$ Graduate in Institut STIAMI, Jakarta
${ }^{7}$ Graduate in Institut STIAMI, Jakarta $-{ }^{8}$ Graduate in Institut STIAMI, Jakarta
${ }^{9}$ Graduate in Institut STIAMI, Jakarta $-{ }^{10}$ Graduate in Institut STIAMI, Jakarta
}

DOI: 10.29322/IJSRP.11.05.2021.p11328

http://dx.doi.org/10.29322/IJSRP.11.05.2021.p11328

\begin{abstract}
This research originated from the complaints of several taxpayers, both individual and corporate taxpayers, whom the authors met regarding errors that are often encountered by taxpayers when inputting and reporting data in the system, either offline or online, both periodic and annual tax returns. The online disruption was caused by frequent inability to login into Directorate General of Taxes website due to network constraints. Not to mention at the time of reporting, suddenly the network could not be connected at all. Some of the taxpayers we met, put a lot of hope for the Directorate General of Taxes to provide certain policies for certain areas where the internet network is not good, in case there is a network disruption when taxpayers try to report their tax returns, especially if this occurs at the deadline of tax return submission. The expected policies of course come with certain reasonable requirements, and we believe Directorate General of Taxes has better understanding to this kind of concept.
\end{abstract}

Index Term : Communication Technology, Directorate General of Taxes (DGT), Internet Network Access, Taxpayers, Tax Policies, Government.

\section{A. Introduction}

\section{Technological development}

There are several milestones in technological development which significantly contributed to the development of Information Technology to date. The first is the invention of the telephone by Alexander Graham Bell in 1875. This finding later developed into the provision of a communication network by cable covering the entire mainland of America, even then followed by the installation of transatlantic communication cables. This telephone network was the first massive human-built infrastructure for global communication.

Entering the 20th century, precisely between 1910-1920, the development of Information and Communication Technology (ICT) was marked by a wireless voice transmission through the first AM radio broadcast. This wireless voice communication soon developed rapidly. This was followed by wireless audio-visual transmission, which took the form of television broadcasts in the 1940s.

Electronic computers, also as a form of ICT development, operated for the first time in 1943. This was followed by the miniaturization of electronic components through the invention of the transistor in 1947 and integrated electronics in 1957.

The development of electronic technology, which is the forerunner of today's ICT, got its golden moment in the Cold War era. Science and technology competition between the Western bloc (United States) and the Eastern bloc (formerly the Soviet Union) 
actually spurred the development of electronic technology through efforts to miniaturize electronic circuits for controlling spacecraft and war machines. The miniaturization of electronic components, through the creation of integrated circuits, at its peak gave birth to the microprocessor. This microprocessor is the "brain" of computer hardware and continues to evolve today.

Telecommunication equipment developed rapidly when digital technology began to be used to replace analog technology. Analog technology is starting to reveal the limits of its maximum exploration. The digitization of telecommunication equipment then converged with computer equipment which from the beginning was a device that adopted digital technology.

Taxes have an important role in contributing to state revenues. As a source of state and national development financing, taxes account for nearly $80 \%$ of Indonesia's total revenues. In addition to requiring active participation of tax officials, the most needed thing is the awareness of taxpayers to pay taxes. In Indonesia, the Directorate General of Taxes carries out the collection of state revenue through taxes.

To adapt to changing times, the Directorate General of Taxes continues to carry out digital transformation in order to improve service quality and increase the effectiveness of supervision of taxpayer compliance. This tax reform is in the form of modernization of tax information technology. One of the reforms made is applying the latest information technology in tax services. In early 2005, the Directorate General of Taxation issued a tax administration system that utilizes technology, namely the e-System or Electronic System. The electronic systems for tax administration include e-Registration, e-Filling, e-SPT, and eBilling. This technology modernization is believed to be one of the important pillars of tax reform because it will be very useful as an effort to increase the tax ratio, tax evasion and encourage taxpayer compliance.

In this sophisticated era, the Directorate General of Taxes is trying to create a new tax information technology which is believed to be successful in supporting tax collection to be more effective and efficient. The core tax technology owned by the Directorate General of Taxes is currently considered too old, with an age of more than 15 years. A system update is required because it is no longer compatible with the current development of information technology, so it cannot be developed further. Mr Robert Pakpahan, Director General of Taxes, said that the Directorate General of Taxes will have new weapons which can support tax collection. The new weapon that he meant was the new Core Tax System. These improvements are in line with the issuance of Presidential Regulation (Perpres) Number 40 of 2018 concerning Reform of the Tax Administration System which was ratified by President Joko Widodo on May 3, 2018. The President hopes that with this Perpres the Directorate General of Taxes will be stronger, more credible, and accountable with an effective process. and efficient.

The core tax system is an information technology system that provides integrated support for the implementation of the duties of the Directorate General of Taxes including automation of business processes starting from the taxpayer registration process, processing notification letters and other tax documents, processing tax payments, supporting inspection and billing, to taxpayer accounting functions. The Directorate General of Taxes has budgeted IDR 3.1 trillion for the construction of a new tax information technology system or core tax system. The Rp3.1 trillion budget will be used to purchase software, CODS tax information system software that has been tested with modifications, and consultations with the system builder.

The core tax system is planned to be built in 3.5 to 4 years with a total procurement of 7 years. The new core tax system is expected to provide a lot of convenience to taxpayers and ensure safety. With the new Core tax system, the Directorate General of Taxes will have an information technology system that can quickly detect non-compliance with high data integrity. This core tax system is equipped with a compliance risk management (CRM) system that will detect the risk profile of each taxpayer in accordance with existing data at the Directorate General of Taxes so that it is easier for taxpayers to implement in accordance with applicable regulations. In addition, this system can also be used to analyze margins which helps the tax office find falsified financial reports or transfer pricing cases. In the future, tax officer will not be able to cheat because this system can find out who opened the taxpayer data. Those who open will be caught in the taxpayer's taxpayer account. The advantage of this sophisticated system lies in its traceability.

Based on the tax reform roadmap, core tax has entered the bidding stage in the third quarter of 2018. The system development can run in the second quarter of 2019 until the third quarter of 2020. Hopefully, in the second quarter of 2021, the Directorate General of Taxes will be able to receive tax returns, payment and registration using the new system. According to Mr. Robert Pakpahan, DGT, the use of this technology may not be sufficient to achieve the target tax revenue ratio of $16 \%$ to gross domestic product in 2019. However, this technology is a step forward to continue making improvements.

From the explanation above, it can be seen that the digital economy is the toughest challenge for the DGT. With the system improvements, for the next 10 years the DGT is believed to be successful in achieving the desired tax revenue target and raising the tax ratio in Indonesia which is still low. In terms of taxpayers, with this advanced system, simple, faster and more effective 
and efficient, it will be easier for them to carry out their tax obligations. Tax officers are also helped by the presence of advanced technology which replaces the role and human labor. Therefore, let's work together to make Indonesia a better one, one of which is by maximizing state revenue through taxes.

Submitting tax online through by Tax Goverment Online e-Filing application makes it much easier for taxpayers to complete their tax obligations. However, as a system, sometimes Directorate General of Taxes e-Filing has problems or errors when it is accessed by taxpayers. Therefore, it is deemed necessary for DGT to prepare and rearrange the system, to make it easier for taxpayers. Apart from that, DGT is deemed necessary to issue the latest policies for taxpayers in certain areas whose internet connection is still classified as inadequate, even for areas with no internet network at all, which causes taxpayers to be late or even not able to report their tax returns.

\section{B. Methodology}

The approach used in this research is a qualitative approach. Qualitative research does not use calculations or is termed scientific research which emphasizes the natural character of the data source. According to Sukmadinata, qualitative research is a study which aimed at describing and analyzing phenomena, events, social activities, attitudes, beliefs, perceptions, thoughts of people individually or in groups.

Based on this methodology, we as authors conducted a case study and a problem that should have been resolved by the government, in this case DGT. These problems are related to DGT system, which still frequently encounter errors and DGT's concerns in understanding certain locations, where network access is still very difficult to support DGT applications and web.

\section{Literature Review}

\section{Technology and Communication}

Information and Communication Technology (ICT) is a broad terminology that includes all technical tools for processing and conveying information. ICT consists of two aspects : information technology and communication technology. Information technology includes all matters relating to the process, usage as a tool, manipulation, and information management. In the Oxford dictionary (1995), information technology described as the study or use of electronic equipment, especially computers to store, analyze, and distribute any information, including words, numbers and pictures.

Rusman, et al. (2012) stated that: "Information technology is a series of stages of information handling, which includes the creation of information sources, maintenance of information channels, selection and transmission of information, selective reception of information, information storage \& retrieval, and use of information".

Communication technology is everything related to the use of tools to process and transfer data from one device to another. Information technology is technology equipment consisting of hardware, software, processes and systems used to assist the communication process.

Thus, Information and Communication Technology contains the meaning of all activities related to processing, manipulation, management and transfer of information between media. Information and communication technology is electronic equipment consisting of hardware and software as well as all activities related to processing, manipulation, processing, and transfer or transfer of information between media (Rusman, et al. 2012: 89).

Before understanding the meaning of Information and Communication Technology, we must understand the meaning of each of the terms technology, information and communication separately.

According to KBBI (The Great Indonesian Dictionary), there are two definitions of technology:

- Technology is the scientific method for achieving practical or applied science goals

- Technology is the whole means of providing goods necessary for the continuity and comfort of human life.

According to Indonesian Dictionary Standart, the meaning of information is information, notification, news or news about something. 
According to Indonesian Dictionary Standart, the definition of communication is sending and receiving of messages or news between two or more people so that the message in question can be understood. Communication also means relationship or contact.

According to the Ministry of Education and Culture, Information and Communication Technology (ICT) contains all technologies related to information handling. Information and Communication Technology is technology related to retrieval, collection, processing, distortion, dissemination and presentation of information.

Quoting Tech Terms, ICT refers to technology that provides access to information via telecommunications. ICT is similar to Information Technology (IT) but the main focus of ICT is on communication technology, such as the internet, wireless networks, cellphones, and other communication media.

Quoting from UNESCO Institute for Statistics, ICT is a diverse set of technologies and resources that are used to transmit, store, create, share, or exchange information. Examples of information and communication technology are: computers; internet (websites, blogs and e-mails); live broadcast technology (radio, television and webcasting); recorded broadcast technology (podcasts), audio and video players and storage devices); telephone (landline, cellphone, satellite, visio or videoconferencing); and others.

What is meant by information technology and communication technology? The following is the definition of information technology and communication technology separately: Information and communication technology can be separated into information technology and communication technology. Information technology is used to process information. An example of information technology is computers. Communication technology is used to move information from source to receiver. Examples of communication technology are telephone and television.

\section{System Software}

In certain information technology, we often hear the term software. Software is divided into various kinds both in terms of distribution and functions. At this time, we will discuss about the definition of system software and its examples. Basically, in general, the function of software is as an intermediary bridge or liaison between hardware.

The definition of system software (system software) is a generic term for a computer system that controls and manages hardware at the first layer. Software will help to manage, process and manage hardware to run optimally. When the hardware is turned on, the system software will process resources, process management and replace the hardware data structure.

According to Oxford Dictionary, system software is "collective system program". From this term, it can be concluded that the system software is a system in a program which acts as a collective controller or in general, jointly and as a whole. It can be said that system software is one of the most important types of software for a hardware, because this software system works on the first layer elements when a device is turned on.

The main example of system software is an Operating System. Examples of system software on computers are Microsoft Windows, IBM, Linux, Apple, Macintosh and others. Examples of system software on smartphones are Android, Blackberry OS, Windows Phone, Symbian, iOS and others. Examples of the system software used by DGT for taxpayers are e-invoice (e-faktur) application, e-SPT for corporate tax, e-SPT for Income Tax Article 21, and so on.

\section{Internet Network}

The internet is a communication network that has the function of connecting one electronic media with another electronic media quickly and precisely. The communication network will convey some information sent via signal transmission with a frequency that has been adjusted. For global standards, the internet uses TCP / IP (Transmission Control Protocol / Internet Protocol).

The term TCP / IP is a form of packet exchange protocol used by various global users. Then, the process for connecting between internet circuits is called "internetworking". According to Onno W. Purbo (2005), an expert of IT, internet is a media used to streamline the communication process using applications such as websites, e-mails, or voip.

Around the 1960s, the US Department of Defense through the ARPA (Advanced Research Project Agency) made a network system called the ARPANET. ARPANET itself is the embryo of the birth of network technology. In America, network technology was still used by a limited circle of campuses around the 1980s. 
Standard TCP / IP protocol began to be published in 1982. Around 1986, the NSFNET (National Science Foundation Network) was founded, which replaced the role of the ARPANET to accommodate research and research activities in America. And, in 1990, the ARPANET began to be derived and with the same service the World Wide Web (WWW) was introduced by CERN.

Finally, in 1993, InterNIC began to develop to register domain names from the public. The history of the internet in Indonesia started in 1994 which was introduced by several experts in the field of information technology at that time.

From year to year, the development of the internet has undergone significant changes in terms of coverage, transmission, speed and usage. In terms of coverage, it includes regional scales or limits on the availability of internet access coverage in certain areas. Currently, many countries are competing to expand their network using satellites. With the help of satellites, they can reach a wider area.

Next is the development of the internet on the transmission of data packets used. At this time, the data transmission process is very different from previous years, since it is now supported by many of the latest and more modern technologies which are in accordance with the concept and understanding of the internet.

In terms of speed, many technology industries have developed several generations of networks. Starting from $2 \mathrm{G}, 3 \mathrm{G}, 4 \mathrm{G}$, the newest is now $5 \mathrm{G}$. To be able to use $5 \mathrm{G}$ internet network technology requires considerable resources for a country.

And finally, the development of the internet in terms of its use. The development of information technology is endless. So, there are lots of changes that have occurred starting from the information, communication and devices used. If the early development of the internet was used for military research needs, now the scope is even more. Such as use for the fields of education, social, political, cultural, military, communication, information, business, and so on.

\section{Taxpayers}

According to the Tax Law Number 6 of 1983 which was updated by Laws Number 16 of 2009 concerning General Provisions and Tax Procedures, taxpayers are individuals or entities, including taxpayers, tax cutters and tax collectors, who have the right and taxation obligations in accordance with the provisions of taxation laws and regulations.

Taxpayers are every person involved in taxation activities including taxpayers, tax cutters and tax collectors.

Because it is called a taxpayer, a person has rights and obligations that must be fulfilled. These rights and obligations are protected by the government through law.

The obligations of taxpayers include, among others, have Taxpayer Identification Number, pay, deduct and report taxes, cooperative during tax audits, and so on.

Meanwhile, the rights of taxpayers include the right to overpayment of taxes, the right to be kept confidential, the right to pay tax in installments and postpone payments by reporting the reasons as well as the right to be exempted from taxation obligations.

\section{Discussions and Results}

\section{Internet network access is not equally distributed and the access is still slow/unstable}

On an official occasion, Minister of Finance Sri Mulyani once issued a statement regarding the condition of several areas Indonesia, whose internet network access capabilities still do not support communication smoothly like in other big cities such as Jakarta, Surabaya, Makassar and others. Not only access to the internet network, but even the electricity network in some areas are still unstable.

Apart from tax reports, the current condition of Covid-19 pandemic is an obstacle for remote areas to conduct online study with minimal internet network access. The world of education has changed since the Covid-19 pandemic. Face-to-face learning between teachers and students is replaced by online study. The implementation of long distance studying between teachers and students by utilizing the internet network sometimes raises its own problems for teachers and students who live in areas with limited internet networks. 
Even though the internet network can be accessed by all regions, the speed of access is an obstacle for several affected areas. We all realize that a strong internet network is a very significant support in the implementation of activities using telecommunications equipment. However, several regions in Indonesia currently have weak internet networks and even tend to be blank spots.

According to the Deputy Chairman of the National Telecommunication Company Association Boris Syaifullah, the superiority of a region can be measured by the strength or failure of the internet network in the area. Areas with strong internet networks can help local communities to communicate.

Director General of Post and Information Administration of the Ministry of Communication and Information, Ahmad M. Ramli, said that as many as 12,548 villages in Indonesia have not been touched by internet signals to this day. According to him, the government is cooperating with operators to flow the network to these villages. Ahmad said that the government and operators currently have a universal service obligation program. Through this program, operators will set aside a portion of their revenue to help the government finance network expansion in areas that have not been touched by the Internet, including $3 \mathrm{~T}$ (frontier, outermost underdeveloped) areas.

Meanwhile, based on data from the Indonesian Internet Service Providers Association (APJII), the number of Internet users in Indonesia in 2018 was recorded at 171.2 million people. This figure is equivalent to 64.8 percent of the total population of Indonesia. Penetration of internet networks in all areas is important since currently the telecommunications sector has become the main pillar of driving the people's economy. Moreover, during the Corona-19 pandemic, almost all activities relied on the digital system.

Ahmad also asked the telecommunications industry to develop its business in the future, not only focusing on one-lane infrastructure development. "But it is a form of convergence. Because in addition to needing as much infrastructure as possible, it also needs to be linked between content, applications and platforms to drive the digital economy," he said.

In Telogoharjo, a village in Giritontro District, Wonogiri Regency, access to information is still very limited, although the provincial road is paved smoothly through the village. Cellular signal does not reach the village either. So starting at mid-2018, Net1 Indonesia, opened services to Telogoharjo. Now the village, which is close to the Pacitan border, has got 4G internet access.

Being in a border area not only creates obstacles for access that are far from the city and lack of entertainment facilities. It seems that smooth surfing in cyberspace is also difficult to achieve when you are in border areas. This was experienced by a tourist from Jakarta, Putri Indrayani, when she was in the border area of Indonesia with Timor Leste, especially when she entered Malacca Regency, East Nusa Tenggara Province. Putri, who works as a journalist, must be patient waiting for a strong internet signal just to send an electronic mail.

In North Kalimantan which consists of five districts and cities: Tarakan City, Tana Tidung Regency, Malinau Regency, Bulungan Regency and Nunukan Regency, internet network access is still frequently disrupted, both in the form of blank spots or slow and insufficient access. Especially if the weather is rainy and cloudy, the network will become unstable.

In a light discussion between one of the taxpayers with the local tax authorities, regarding to being late in tax reporting due to network error, the answer from the tax authorities is somehow unexpected since the system will most likely detect it as a late filling or considered as not reported, which will followed-up with a certain fine or penalty.

In another response, the local tax authorities suggest to submit tax returns long before the deadline in order to minimize internet access problems when it's heavily accessed towards the reporting deadline. This idea is not wrong, however, the tax authorities must also understand the condition of the taxpayer. Because taxpayers do not only deal with their taxes, but there are many things which have to handled. The authors suggest that the Government, in this case DGT, must issue new policies without reducing state revenues and without making it more difficult for taxpayers to report and pay their taxes.

\section{Recommendations to the Directorate General of Taxes regarding Network Access for policies for taxpayers.}

Submitting tax reports online, both annual and monthly, are not difficult, even it takes only less than ten minutes to process as long as internet network access is good, but when internet network access is not good, it will be difficult to access DGT website, especially during the deadline of reporting. This happened not only in locations where internet network access is not strong and good but also in areas with good internet network access.

All Indonesian citizens who are already working or have income, are required to pay taxes and report the annual tax returns online. Apart from being more effective and practical, this online system also offers many benefits for taxpayers. One of them is 
saving time. Even so, online annual tax return reporting still has its limit. One of them, may face technical problems such as difficulty in accessing the system from the DGT website, as well as from the official partner application. Several problems faced by taxpayers are due to poor internet network access or because DGT internal system still has several errors which make it difficult for taxpayers.

If you are familiar with reporting taxes online using DJP Online, it is likely that you are familiar with the error code or errors that appear on DJP Online website. DGT online website has a variety of error codes that can appear, starting from the registration process, logging in or during the tax reporting process.

Each error code has its own cause and solution, this will certainly be an obstacle for those of you who are beginners in online tax filing. Here are some error codes that often appear when reporting taxes along with their solutions:

\section{- Server Not Found 404 or error 405}

Try clicking the "Back" button on the browser or refreshing the DJP Online page and re-login.

\section{- $\quad$ Error 500 or Error 502}

To solve this error message, make sure you already have a stable internet connection. Don't forget to also use the Google Chrome, Microsoft Edge, or Mozilla Firefox browsers. If everything is functioning normally, but the text still appears, it means that the DJP Online server is down. This means that it cannot be accessed for a while, because too many visitors are accessing it at the same time.

\section{- $\quad$ Error Code: REG008}

If you encounter this error message when logging in using a registered NPWP, try accessing the DJP Online password reset page. Then in the forgot email section, click "Yes" and enter your active email address. Check your inbox / email inbox, then click the link that was sent and create a new password. This way, you don't have to re-register again.

\section{- $\quad$ Error Code: SO002}

When this error code appears, it means that the data was not found because you have not registered with e-Filing DJP Online. Try to re-register on DGT Online registration page.

\section{- $\quad$ Error Code: SO004}

This error code appears if you have received an activation email sent by DJP Online but have not clicked on the link.

\section{- Error Status Code: 0}

This error code appears when you are about to send a tax returns. To solve this error code, try to check the data on the asset report. If there are still zero values, fill in first.

\section{- Error 500: java.lang.NullPointerException}

If you find this error code, try updating your profile, especially the registered phone number.

\section{- $\quad$ Error 403 or Error 405}

This error message is displayed because you do not have the authority to access this service. Try clearing your browser cache and restarting your computer. If you don't have access yet, then you need to come directly to the registered KPP.

\section{- $\quad$ Error 732: Internal Server Error}

This error code will appear if the internet connection is not stable. You don't need to panic, just click the refresh button in your browser. 


\section{- The words home? Acces_token = nul appear}

The URL Error on this one is slightly different from the previous error message, if this article appears when you are doing e-Filing at DJP Online, this can be caused by two things. First, you have opened a web page for too long without any activity (idle), or you have logged in with another device / computer but forgot to log out.

The errors code above are the obstacles which are often encountered at the time of tax reporting caused by DGT system, which is still inadequate and also because of network access. DGT is one of the government agencies that manages the veins of state revenue, therefore DGT should create a more advanced system such as the banking system which is very rarely encountered errors and system errors. The authors strongly believes that in fact something similar can be prepared and made an advanced system to make it even easier for taxpayers to carry out their obligations, at least the constraints of errors which often encountered will not get in the way when taxpayers submitting their tax returns.

The list of error codes mentioned above seems to represent a systematic error. This error indirectly describes the existence of software which seems to have become part of the purpose of the application being made, where the taxpayers disagree and even feel disturbed by it, moreover the majority of taxpayers certainly do not really understand the error. The majority of these conclusions were drawn based on the IT capabilities of several taxpayers who had met.

Therefore, after careful consideration of several literatures and discussions with taxpayers which have been previously presented in this journal, for the common good, both for the interests of the nation and the state, which of course do not conflict with the needs of citizens' life and other matters, there are some proposals to DGT as follows:

1. With the experience of the application or software used by the Bank or other institutions where the probability of error is very slim, it is better for DGT to consider a software application that is more advanced than before. DGT should imitate other advanced systems where error is very rarely found.

Frequently updating the system is not the most appropriate method. It is better for the existing software to be upgraded with a long distance interval, provided that at the time of upgrading it is carried out steadily, rather than gradually changing and upgrading the system but the results are not satisfactory for taxpayers.

Even with the advanced software and with a little errors, there is still a chance that taxpayers are not enthusiastic regarding tax reporting, especially if they have encountered a lot of trouble. When a taxpayer goes to the tax office, they have to wait for a long queue, not to mention finding that traffic jams are activities that are very detrimental to taxpayers because a lot of time is wasted. Therefore, it is highly recommended for DGT to finalize the applications or software used for tax purposes so that later errors can be minimized.

The tax software error reflects the unpreparedness of the tax application. Moreover, the majority of taxpayers do not understand and are less familiar with IT.

2. Regarding internet network access, which is still frequently found in some areas, DGT must take new breakthroughs and policies that are intended for all areas with very limited network access capabilities.

DGT issues and designs one of the rules and policies for those regions. These policies are certainly not in regular conditions, however, these conditions are prepared for conditions that are not possible, with the impact on the taxpayer to be subject to sanctions.

For example, let's say a taxpayer, A, who is located in Tarakan, North Kalimantan. At the end of April 2020, the network connection was completely off so it was not possible to submit his annual tax returns. Normally, this will results in fines / sanctions. With the proposed policy, the concerned taxpayer can request for an extension time to submit his tax returns to DGT so that he is not sanctioned, by submitting evidence indicating that at that time internet network could not access to DGT website.

\section{Conclusion}

The current advance of technology should be the main support for anyone who needs it, and it is very unfortunate if an innovation plan especially related to technology actually creates confusion for its users. Tax applications which have been used often encounter errors or other obstacles. Starting from this point, DGT as a institution which is related to all tax software or 
applications, should prepared to applications or software which are more advanced and minimize the errors which are often encountered by taxpayers. As one example, the software used by banks or other institutions should be used by DGT so the possibilities of errors can be prevented to provide a smooth connection and reduce the confusion from the taxpayers.

There are still some areas that have difficulty accessing the internet network. We suggests to DGT to facilitate certain rules and policies to certain areas which still having difficulty accessing the internet network so that when they experienced troubles when submitting their periodic or annual tax returns due to bad connection, they won't be sanctioned.

\section{References}

Al Ghani, Yudis. 2021. Sejarah Perkembangan Teknologi Informasi dan Komunikasi. https://www.sma-ypunila.sch.id/artikel1055-sejarah-perkembangan-teknologi-informasi-dan-komunikasi.html. Accessed on March 25, 2021.

Novitasari, Lela. 2021. Modernisasi Teknologi Informasi Perpajakan di Era Ekonomi Digital. https://www.pajak.go.id/id/artikel/modernisasi-teknologi-informasi-perpajakan-di-era-ekonomi-digital. Accessed on March 25, 2021.

Rusman dkk. 2016. Pengertian Teknologi Informasi dan Komunikasi. https://edel.staff.unja.ac.id/blog/artikel/PengertianTeknologi-Informasi-dan-Komunikasi.html. Accessed on March 25, 2021.

Robith Adani, Muhammad. 2020. Pengertian Internet, Sejarah, Perkembangan, dan Manfaatnya. https://www.sekawanmedia.co.id/pengertian-internet. Accessed on March 28, 2021.

Online Pajak. 2018. Pengertian Wajib Pajak Berdasarkan UU KUP. https://www.online-pajak.com/tentang-pajak/pengertianwajib-pajak. Accessed on March 28, 2021.

Kompas.com. 2020. Pengertian Teknologi Informasi dan Komunikasi (TIK) dan Contohnya. https://www.kompas.com/skola/read/2020/09/10/194000969/pengertian-teknologi-informasi-dan-komunikasi-tik-dancontohnya?page=all. Accessed on March 28, 2021

Lexi J, Moleong, Metodelogi Penelitian Kualitatif, (Bandung: PT. Remaja Rosda Karya, 2002), hal. 2.

Nana Syaodih Sukmadinata, Metode Penelitian Pendidikan, (Bandung: PT. Remaja Rosdakarya, 2007), hal. 60

Government of Indonesia. 2008. Constituion No. 208 year 2007. Which Regulates General Provisions and Tax Methods. RI Gazette of 2007 No. 39. Jakarta: State Secretariat. 